\title{
ОСОБЛИВОСТІ ПРОВЕДЕННЯ ЛЕКЦЙНИХ ЗАНЯТЬ 3 ДИСЦИПЛІНИ “МЕДИЧНА БІОЛОГІЯ” У СТУДЕНТІВ, ЩО НАВЧАЮТЬСЯ АНГЛІЙСЬКОЮ МОВОЮ
}

Н. I. Фрич

\author{
ДВНЗ “Івано-Франківський начіональниймедичний університет”
}

\section{FEATURES OF REALIZATION OF LECTURES AT THE DISCIPLINE "MEDICAL BIOLOGY" IN STUDENTS WHO STUDY IN ENGLISH}

\author{
N. I. Frych \\ SHEI "Ivano-Frankivsk National Medical University"
}

\begin{abstract}
У статті розглянуто актуальні проблеми, що виникають при підготовці та проведенні лекцій з дисципліни “Медична біологія” для студентів, що навчаються англійською мовою. Запропоновано шляхи та методи удосконалення подання лекційного матеріалу для покращення розуміння термінів та понять і успішного засвоєння дисципліни. Обгрунтовано доцільність використання мультимедійних технологій для проведення лекцій.
\end{abstract}

\begin{abstract}
Actual problems, that arise up during the preparation and realization of lectures on discipline "Medical Biology" for students who study in English, are considered in the article. Ways and methods of improvement of presentation of lecture material are offered for the improvement of understanding of terms and concepts and successful mastering of discipline. Expediency of the use of multimedia technologies is reasonable for realization of lectures.
\end{abstract}

Вступ. Університети нашої країни поступово набирають обертів по залученню іноземних громадян із метою надання освітніх послуг. Не є винятком і Івано-Франківський національний медичний університет. Щорічне зростання кількості іноземних студентів, що навчаються в нашому вузі, ставить нові завдання як перед університетом, так і перед кожною кафедрою та вимагає їх конструктивного вирішення.

Однією з актуальних проблем сучасної педагогіки вищої школи є удосконалення організаційної структури та методів управління навчальним процесом, що пов'язане з використанням традиційних форм навчання, наукової організації навчального процесу, а також впровадження нових форм навчання в лекційний курс [1].

Тому метою роботи є пошук шляхів удосконалення методики та засобів проведення лекцій з дисципліни “Медична біологія" для студентів 1 курсу, що навчаються англійською мовою.

Основна частина. Викладання дисципліни "Медична біологія" розпочинається в першому семестрі і триває протягом першого року навчання як для студентів медичного та стоматологічного факультетів,

(c) Н. I. Фрич так і для студентів факультету підготовки іноземних громадян. Для англомовних студентів медична біологія читається уже понад десять років, що і дало змогу набути певного досвіду роботи в організації навчального процесу.

Беручи до уваги специфіку викладання цієї дисципліни (акцентується увага на рівнях організації життя з урахуванням особливостей організму людини, біології клітини та процесах, що в ній відбуваються), матеріал подається таким чином, щоб отримані студентом знання були тісно пов' язані з подальшим вивченням спадкової патології, паразитарних захворювань на теоретичних і клінічних кафедрах і могли бути використані майбутнім лікарем в його практичній діяльності.

Однією з особливостей дисципліни “Медична біологія” є великий об'єм теоретичного матеріалу, винесений на лекційні заняття, який за браком годин (згідно з типовою навчальною програмою) не може бути поданий у повному обсязі. Тому кожна лекція вимагає ретельної підготовки викладача і повинна відповідати таким вимогам, як науковість, доступність, єдність форми і змісту, емоційність викладу [2].

Враховуючи труднощі у засвоєнні студентами матеріалу, що пов'язані з мовним бар'єром, різним 
рівнем підготовки, недостатньою кількістю оригінальних англомовних літературних джерел, календарнотематичний план лекцій та практичних занять складений так, що матеріал, які студенти одержують на лекціях, передує тому, що вони вивчають на практичних заняттях. Кожна лекція адаптована до читання та розуміння студентами-іноземцями, матеріал викладається у стислій формі, але викладається головне, важливе для розуміння. Матеріал лекцій подається таким чином, що спонукає студентів до логічного мислення, викликає запитання, що переростають у короткі дискусії. Для покращення засвоєння нової теми у лекціях використовуються схеми, таблиці. Проте основна роль приділяється мультимедійним технологіям, використання яких $€$ найбільш ефективним способом демонстрації інформації.

Застосування мультимедійної лекції $€$ незамінним для контингенту іноземних студентів, більша частина 3 яких не в змозі одночасно записувати представлений матеріал та слухати пояснення лектора. Такий спосіб подання інформації сприяє підвищенню концентрації уваги студентів, процесів розуміння i запам'ятовування, формуванню чітких уявлень, засвоєнню теоретичних знань, активізуючи пізнавальну діяльність студентів. Окрім того, такий вид діяльності дозволяє викладачеві суттєво зекономити час, який зазвичай витрачається на написання біологічних термінів, схематичне зображення матеріалу на дошці, i, таким чином, дає змогу більш глибоко пояснити навчальний матеріал [3].

Ще одним хорошим способом для мотивації навчання $є$ демонстрація відеоматеріалів з цікавою проблематикою - наприклад, механізм мейозу та його

\section{Списоклітератури}

1. Особливості викладання гістології, цитології та ембріології іноземним студентам / К. С. Волков, Л. В. Якубишина, Л. Я. Федонюк [та ін.] // Медична освіта. - 2002. - № 3. C. 122.

2. Балагурова В. А. Какой должна быть современная лекция / В. А. Балагурова // Фармация. - 2007. - № 3. C. $47-48$.

3. Ющенко Ю. П. Використання інформаційних технологій у процесі викладання соціально-гуманітарних дис- біологічне значення або вплив паразитів на організм людини. Проте запропонований відеофрагмент може бути показаним не до кінця. Такий метод стимулює цікавість до проблеми. Щоб знайти відповіді на запитання, студенту потрібно або запитати викладача, або самостійно відшукати такі відеоматеріали в Інтернеті за поданими посиланнями.

Згідно з літературними даними [4] розвиток інформаційних технологій дає змогу студенту користуватися найновішими науковими даними та відкриттями. Проте така самоосвіта займає дуже багато часу, якого студентам медичних навчальних закладів не вистачає. Зазвичай, найбільше потерпають у цій ситуації студенти-іноземці, які на процес навчання затрачають дуже багато часу, а студенти з арабських країн - ще і на подолання мовного бар'єра.

У зв'язку з вищесказаним, нами розроблені тексти лекцій, якими можуть додатково користуватися бажаючі студенти. Рекомендовано ознайомитися 3 даними лекціями на сайті університету.

Висновки: 1. Лекція і надалі повинна залишатися основною формою навчання для засвоєння теоретичного матеріалу. Текст лекцій повинен бути наповнений ілюстраціями та добре підібраними відеоматеріалами.

2. Проведення лекцій з медичної біології вимагає доброї базової підготовки та достатнього рівня знань англійської мови у студентів факультету підготовки іноземних громадян.

3. Застосування мультимедійних технологій для англомовних студентів $\epsilon$ необхідною умовою вивчення предмета.

циплін / Ю. П. Ющенко, Л. П. Кустарьова // Вісник проблем біології і медицини. - 2013. - Т. 1 (104), вип. 4. C. $74-75$.

4. Побуцький О. О. Застосування інноваційних методів унаочнення та візуалізації у підготовці медичних кадрів / О. О. Побуцький // Галицький лікарський вісник. - 2010. T. 17, №2, ч. 1. -C. $126-128$. 